\title{
Chapter 5 \\ The Inheritance of Island Yi \\ and the Acculturation of Maritime Fan \\ in the Han People on Southeast Coast \\ of China
}

The Han (汉) people of southern China living in the coastal regions lying to the south of the lower reaches of the Yangtze River show a series of distinctive essences of physique, language or dialect, lifestyle and economic pattern, religion and worship of supernatural spirits, cultural orientations to the oceans and maritime character and so on. It is a special branch of the unity of the "Assimilation and Integration of Pluralistic Cultures" of the Chinese people, which is obviously different from the northern Han nationality centering on the Central Plains (Wu, C.M. 2004, 2007).

The maritime orientation of "living on boats as home, depending on sea as lifestyle, trading with Maritime Fan (诸番)" was the most prominent characters of the Han people in south of China, especially in the southeast coast in Zhejiang, Fujian, and Guangdong. Though the maritime culture was not originally the major feature of ancient Chinese civilization which was characterized in terrestrial farming culture, it was one of the cultural features of Han people in the southeast coast of China. These Han people were the main navigators of Junk and maritime merchants of ancient China since Tang and Song dynasties on, stubbornly constructing the cross-border maritime economy along the Maritime Silk Road in the Seas Surrounding China. They were the main force of the coastal maritime sociocultural community and the elite of the Chinese maritime civilization in the past two thousand years, being active as "upper class society" in the series of the node seaports along the Maritime Silk Road such as Guangzhou (广州), Quanzhou (泉州), Yangzhou (扬州) and Mingzhou (明州). Under the strict maritime ban of Ming Dynasty, "the maritime merchants turned to be illegal pirates when the sea trade was forbidden" (Deng, R.Z. 2007: 673). These private maritime merchants grouped in the southeast coast of China violated the ban policy of empire and traded with “barbarian” Island Yi (岛夷) and Maritime Fan “illegally". The more severely the government restricted the non-governmental maritime trade, the more powerfully these private merchants violated the restrictions, rose to be a lot of big and small armed smuggling gangs in the southeast coast, and spread into overseas in the East and Southeast Asia. Although they were regarded as "illegal", "pirates" and "Japanese pirates" by the officials of the Ming empire, objectively they were sea

C. Wu, The Prehistoric Maritime Frontier of Southeast China,

The Archaeology of Asia-Pacific Navigation 4,

https://doi.org/10.1007/978-981-16-4079-7_5 
heroes promoting the progress of maritime social, cultural, and economic system in Seas Surrounding China. About five hundred years ago, with the arriving of the European navigators and the abolishing of sea ban system of empire since late Ming Dynasty, "the pirates turned to be legal maritime merchants when the sea trade was allowed" (Deng, R.Z. 2007: 673). The private merchants in the South China Sea had made great contributions to the early globalization of the social economy in East Asia, resulting the introduction and assimilation of modern sciences, technologies, and cultures from the West, through the cross-border trade between the mainland coast of southeast China and islands in East and Southeast Asia, and the maritime connection indirectly with Euro-American societies. Their striving enriched the connotation of the integrated pluralistic cultures of ancient Chinese civilization. Therefore, the maritime features of the Han people represented by the ancient private merchants of southeast coast of China have been the spiritual connotation of the maritime culture in Seas Surrounding China, and the indispensable treasure of the ancient Chinese civilization.

The formation of the maritime character of the Han people in south of China originated from the ecological shaping of oceanic environment in southeast coast of China and the assimilation of the diverse maritime ethnic cultures in last thousands of years. The accumulation and assimilation of the prehistoric and early indigenous Bai Yue (百越), Island $Y i$ and proto-Austronesian of the Maritime Region of Southeastern Asia, as well as the immigration and acculturation of the overseas ethnic groups of foreign Maritime Fan since the medieval ages, were the two main sources of the formation and development of the unique maritime cultural character of the Han people in southeast coast of China (Wu, C.M. 2011b, 2017).

\subsection{The Indigenous Island Yi's Origin of the Maritime Essence of the Han People in South China}

Though the mainstream of the Han nationality was the lineal descendant of the Huaxia people of Central Plain, the predecessors of maritime essence of Han nationality in south China were the frontier cultures of Island Yi and Bai Yue in the geopolitical order of the "Central Nation-Peripheries Barbarians in Four Directions-Four Seas", in the discourse and records of ancient China. Relying on Huaxia of Central Plain, facing and territorially connecting with the maritime "barbarian" Island Yi and Austronesian on southern sea, the Han nationality living in the southeast coast, mixed and acculturated with local indigenous maritime "barbarian" Islands Yi and Bai Yue in long history of the "Assimilation and Integration of Pluralistic Cultures" of ancient Chinese civilization. They prominently presented the maritime characters and were the earliest maritime culture founders and sea heroes of ancient China. In the process of the cultural evolution of ancient China, from the complex and regionally pluralistic prehistoric cultures to the national unification in the Qin and Han empires, the maritime barbarians of Bai 
Yue and Island $Y i$ in the mainland southeast coast of China gradually assimilated and integrated into the unified nation with the core of Huaxia and Han nationality, setting the maritime cultural context of ancient population of southeast coast of China.

In the vision of Huaxia and the Han nationality, the ancient Bai Yue people were the "hetero-culture" and "totally different from ours" who lived along the coasts and islands, wore colorful straw and bark woven clothes, collected and ate marine shellfish, played and ate with snakes, and were good at using canoe and boats. Chapter of “Areas within the South Sea” (海内南经) of the Classic of Mountains and Seas (Shanhaijing 山海经) records: “The aboriginal people of both $\mathrm{Ou}$ (瓯) and Min (闽) live in the sea. It is said that the mountain of Min state is located in the sea, or next to the northwest of the sea" (Yuan, Ke 2014: 237). "Tribute of the Yu Period" (禹贡) in the Book of Early History (Shangshu 尚书) states that “The barbarians on the islands wear straw clothes, make and wear bark and straw woven clothes, weave bamboo, use marine shells as decorations, live along the rivers and seas, and reach as far as Huaihe (淮河) and Shishui (泗水) rivers" (Ruan, Y. 2009: 312-313). These records depicted the maritime landscape and coastal geography where Islands $Y i$ and Bai Yue people dwelt, as well as ecological products of the tropics and subtropics regions such as their "primitive" dresses made of straw and barks, marine shell decorations (Shao, W.P. 1989; Wu, C.M. 2010). These indigenous Yi and Yue people were also characterized by enjoying sea food and good at sailing boats. The "Record the Kings Meeting (王会解)” of the Lost Historical Literature of Zhou Dynasty (Yi Zhoushu 逸周书) records: “The Eastern Yue (东越) people enjoy marine shell clams, $\mathrm{Ou}$ people like to eat snakes. The Yu Yue (于越), Gumei (姑妹), and Gongren (共人) people like to eat marine shellfish and crabs” (Huang, H.X. et al. 2007: 833844). The chapter of "People Live in Five Directions (五方人民)" of the Biography of the Things and Cultures (Bowu Zhi 博物志) records that "People in the southeast ate aquatic products, while people in the northwest ate domestic animals. Southeast people eating aquatic products considered turtles, clams, snails, clam and alike as delicious food" (Zhang, H. 2012: 10). The chapter of the "Biography of the Yue Territory (越绝外传记地传)” of the History of the Lost Yue Ethnicity (Yuejueshu 越 绝书) records that “The character of the aboriginal Yue is crude and rash. They live along mountainous coast and travel by water, taking boats with oar as their main transportation tool. They skillfully sail the boat as fast as the howling wind" (Yuan, Kang 1985: 57-58). The chapter “Master Strategy Research (主术训)” of the Book of the Prince of Huainan (Huan'nanzi 淮南子) records that "despite being a great lord, the wise emperor Tang (汤) of Shang Dynasty was incapable of sailing the boat on rivers and lakes as indigenous Yue people easily did" (Liu, A. et al. 2010: 126).

In the southeast areas of Zhejiang, Fujian, Taiwan, Guangdong, and Guangxi, densely coastal settlement sites of Neolithic and Bronze ages have been investigated, which reflect the marine adaptation and maritime cultural development of early indigenous people in prehistory and early history of China (Yuan, J. 1995; Jiao, T.L. 2012; Wu, C.M. 2019). In the lower reach of Qiantangjiang (钱塘江) River, Neolithic culture spread from the coast to the offshore islands, representing the occurrence and early development of the maritime culture along the coast of East 
China Sea (Cao, J. 2012). The indigenous maritime cultures on the coast of Fujian occurred 8000 years ago, and hundreds of sites of Neolithic and early Metal age, being densely situated at estuaries and beaches around the lower reaches of the Minjiang (闽江) River, and on a number of nearshore islands, have been discovered, highlighting the development of the maritime settlements landscape of the early indigenous Seven Min (七闽) people as the record "Min lives in the sea" in the Classic of Mountains and Seas (Wu, C.M. 1995, 1996a; Wu, C.M. et al. 1998: 143-153).

Along the north coast of the South China Sea with the Pearl River (珠江) Delta as the center, more than one hundred shell mounds and dune sites dating back to 6000-3000 years ago have been found. The shell mounds were generally located in the delta and estuary, and the dune sites were usually found along the coast or on the islands of the estuary of the Pearl River, reflecting the occurrence and the early development of the maritime settlement of Southern Yue ancestors (Zhu, F.S. 1994; Yuan, J. 1999). Dozens of Neolithic coastal dune and shell mound sites have also been found in Hainan island, dating from 5000 to 2500 years ago with the features of dense distribution and marine fishing on the coast around the island, they were the prehistoric maritime cultural heritages of indigenous Island $Y i$ and Daner (儋 耳) (He, G.J. 2012; FSCAT-IA-CASS et al. 2016).

Archaeological discoveries have also proved that the prehistoric ancestors of Bai Yue were very active in early seafaring. Hundreds of continental islands are scattered along the southeast coast of China, and the Neolithic cultural contents unearthed on these islands are basically consistent with the those on the coast of mainland, reflecting the primitive maritime traffics between the mainland and islands. The Neolithic cultural series of Taiwan island presents successively the Corded Pattern Pottery Type, Red Fine Pottery Type, Gray and Black Stoneware Type, and Check Pattern Stamped Pottery Type. They have been dated from 5000 to 2000 years ago and studied as the result of several major cultural movements and indigenous emigrations from the mainland to the island in prehistoric times (Li, J.T. et al. 1992). Similar prehistoric cultural communications and the dispersal of maritime groups also took place in Bashi Channel between Taiwan and Luzon, and other numerous sea straits in southeast Asia and the Pacific archipelagos, forming the Proto-Austronesian cultural circle based on the dissemination and interaction of prehistoric cultures over the vast oceans (Lin, H.X. 1958b; Chang, K.C. 1987a; Bellwood, P. 1997: 201-202). This is a huge cross-border maritime cultural community between the indigenous peoples of Proto-Bai Yue system in southeast coast of China and Proto-Austronesian in southeast Asia and Pacific archipelagoes, showing the vitality of the indigenous maritime cultural tradition in the Seas surrounding China (Wu, C.M. 2003).

The Han people in south of China, being a distinctive regional group of the Han nationality in Chinese unity, had been the historical result of two-way cultural assimilation of both the indigenization of the Han population who migrated from the Central Plain and North to the indigenous regions of Bai Yue in the southeast of China, and the sinicization of local Bai Yue ethnicities (Wu, C.M. 2004, 2007). The military and political unification since the Qin and Han dynasties promoted the ethnic group's emigration of Han population in large scale from the Central Plain 
and North to the original land of Bai Yue in southeast coast, and the two-way ethnical assimilation of Han and Yue. The sinicized Yue people preserved in different degrees the indigenous maritime essences of their prehistoric ancestors, while the indigenized Han population accepted and inherited a series of local Yue cultures in their resettling lands of southeast coast. This two-way assimilation of Han and Yue cultures made richly the cross-cultural inheritance and accumulation in southeast coast of China, of which the indigenous maritime culture was the most significant aspect.

Firstly, since the Han and Tang dynasties, the maritime population of Han nationality living along the coastal region and on the islands of southern China, whether the lower class of boat people Dan (蛋) in the fishing villages of countryside, or upper class of maritime merchants in the seaport metropolis, were directly or indirectly originated from the indigenous "barbarians" of Island Y $i$ and Bai Yue who were "good at using boats".

The boat people Dan was the distinctively representative of the lower class of the maritime society of Han generally living in the fishing villages of the southeast coast since the Han and Tang dynasties, who was mainly originated from the indigenous Bai Yue (Chen, X.J. 1946; Han, Z.H. 1954; Huang, X.M. 1990). The “Biography of Southern Barbarian” (南蛮传) of the History of Sui Dynasty (Suishu 隋书) records: “The southern Barbarians Man (蛮) with diverse ethnicities live together with Huaxia people in south of China, such as the tribes Dan, Rang (獽), Li (俚), Liao (僚) and $Y i$ (狏) who are without a chieftain. They live in the caverns of mountain, and their ancestors are the so-called Bai Yue ethnicity in the ancient time" (Wei, Z. et al. 1982: 1831). The boat people Dan had been a famous maritime ethnicity and the main force of maritime economy in southeast region of ancient China, known as a series of distinctive names with marine characteristics such as “Houseboat Guy (Youting Zi, 游艇子)", “Boat Family (Tingjia, 艇家)”, “Water People (Baishui Lang, 白水郎)”, and “Family on Boat" (Shuiju Chuan 水居船, Fig. 5.1). The section of "Lingnan Road First (岭南道一)" in the Vol. one hundred and fifty-seven of the Geographical Record of the World in Taiping Reign (Taiping Huanyu Ji 太平寰宇记) records: “The boat people Dan in Xinhui (新会) of Guangzhou were administrated by county municipal office, who were born, lived and fished on the seas and rivers, and sailed across the big waves. They would mostly die if they moved to live on land, just as the Water People in East Road of Southern Yangtze River (江南东道)" (Yue, S. 2007: 3021). The section "Record of Barbarian Man" in the Records of Geography and Folkways in Guilin (Guihai Yuheng Zhi 桂海虞衡志) states: “The boat people Dan are in fact the barbarians living on the sea water. They live on boats and make living by gathering and eating marine foot without cooking. Only these boat people are able to dive and see in the deep water, and catch clams underwater in the pearl ponds in Hepu (合浦)" (Fan, C. D. 1986: 118). The “Biography of Taiding Emperor (泰定帝纪)" in the History of the Yuan Dynasty (Yuanshi 元史) records that in the July of the first year of Taiding (泰定) Reign (AD1293), the office made “the boat people Dan who gathering pearls underwater in Guangdong and Fujian being civilian, and exempted them from paying tax of one year" (Song, L. et al. 1976: 649). The section "Method of 
Fig. 5.1 Boathouse of the Chao Lae in Thailand (Cited from Princess Maha Chakri Sirindhorn Anthropology Centre in Bangkok 2007)

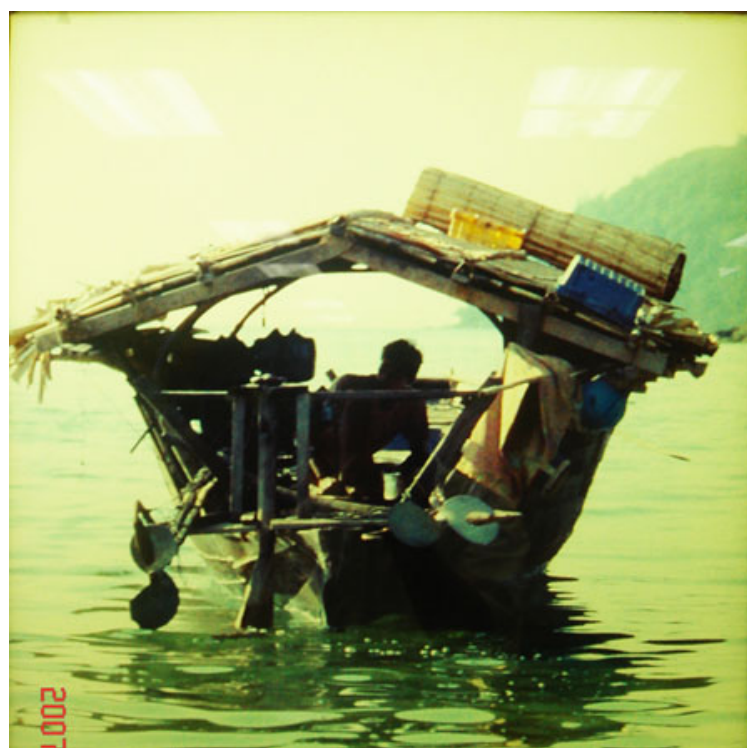

Gathering Pearls in the Sea (珠池采珠法)” in the Diary in Eastern Coast of Water (Shuidong Riji 水东日记) of the Ming Dynasty says: “The boat people Dan collected pearls by the boat. They anchored the boat on the sea around the pearl situs and set a short rope from the boat into water by stone weight. Then the Dan salvager bound the string on his waist, dived into the deep sea along the rope and collected the pearls underwater" (Ye, S. 1980: 54). The section of "East Road of Southern Yangtze River (江南东道)" in the Vol. one hundred and two of the Geographical Record of the World in Taiping Reign records: "The Water People, or Houseboat Guy, were the barbarians $Y i$ (夷) in Quanzhou who live on the boats as permanent homes all year round. They moved constantly on the water with boat famous as Liaoniao Chuan (了鸟船), which was made in both sharp pointed stem and stern, and flat and wide midship suitable for sailing in rough wind and wave" (Yue, S. 2007: 2029-2031). The section of “Other Works (杂录)” in the Vol. thirty-one of the Complete works of Cai Xiang (Caixiang Quanji 蔡襄全集) also records that "the Family on Boat in Futang (福唐) county was the maritime people whose whole family lived on a boat all year round" (Cai, X. 1999: 691).

The ancient maritime merchant of southern China was originally active in the coastal seaports of southeast region since the Han Dynasty on and were the distinguished representatives of the upper class of maritime society in south of China for more than 2000 years. The chapter of "Annals of Geography" (地理志) of the History of the Han Dynasty (Hanshu 汉书) records: “Pangyu (番禺) was one of the metropolis cities where many merchants were attracted to trade rhinoceros, ivory, hawksbill turtle, pearls, silver, copper, fruit, and cloth there and got rich" (Ban, G. 1962: 1670). Vol. nine of “Chronicles of Locality" (方域) in the Collected Important Administrative Statutes of the Song Dynasty (Song Huiyao Jigao 宋会要辑稿) states: 
"There were many foreign and Chinese merchants living together in Guangzhou where had no city wall" (Xu, S. 1957: 7472). The Vol. sixteen of the Works Collection of Authority $W u$ Wenzheng (Wu Wenzhenggong Ji 吴文正公集) of Yuan Dynasty records: "Quanzhou was the metropolis city in Seven Min region of ancient Fujian, where the exotic treasures and rare curios from remote foreign states were imported and stored. It was the biggest seaport in the world with many business tycoons and wealth merchants residing" (Wu, Cheng 1985: 300-301). These maritime merchants continued trading with foreign states around the South China Sea and even over the Indian Ocean during Song and Yuan dynasties, as the chapter of the "Foreign Barbarian Fan States (诸番国)" in the Vol. two of the Interlocution on the History of South Coast of China (Lingwai Daida 岭外代答) records, “The Chinese maritime merchants who wanted to trade with Arabian countries should sail to stop at Gulin (故 临) state and change a small boat to go on the navigation in one month following the south wind. Their sailing of round-trip should take two years" (Zhou, Q.F. 1996: 37).

During the Ming Dynasty, these traditional maritime merchants were discontented with the private trading ban of the Ming empire, and were passively changed from legal maritime merchants of Tang and Song dynasties to "illegal" merchant group emerged and "violated" the law of sea ban under the "Tributary Trade" system of Ming Dynasty. This changing situation was recorded in historical documents of Ming Dynasty, "The pirates turned to be legal maritime merchants when the sea trade was allowed, and the maritime merchants turned to be illegal pirates when the sea trade was forbidden" (Deng, R.Z. 2007: 673). These maritime merchants who were charged as "Pirates" or "Japanese Pirates" by the officials of the Ming government were basically and objectively maritime heroes for trading over the seas surrounding China, with the adventurous and rebellious spirits and by armed "smuggling". There had been dozens of "illegal" maritime trade groups in the middle and late Ming Dynasty, among them, the largest, most powerful and influential was Zheng's maritime merchant group, that was Koxinga (国姓爷), which dominated and controlled maritime trade between the South Ocean, East Ocean, and Japan Sea for decades (Lin, R.C. 1987: 85-130). These maritime merchants with thousands of year's tradition of navigation trade were familiar with the sea routes and water channels over the "Four Seas" and "Four Oceans" in Seas Surrounding China, skillful with seafaring techniques, and brave in oceanic adventure, directly or indirectly inherited the prehistoric and ancient maritime cultures of indigenous Island Yi and Bai Yue people who were good at using boats (Fig. 5.2).

Secondly, the indigenized Han people in the coast of southern China inherited a series of cultural connotations of prehistoric and early historic Islands Yi and Bai $Y u e$, including the indigenous sea gods worship, maritime folklores, and lot of other primitive maritime cultural features.

The well-developed primitive animism and broad worship of the supernatural ghosts were the distinctive feature of the ancient Bai Yue culture, which had been discriminated and recorded by Huaxia and Han literatures since Han Dynasty. Both the "Records of Sacrifice to Heaven and Earth" (封禅书) of the Records of the Historians (Shiji 史记) and the “Annals of Sacrificing” (郊祀志) of the History of 


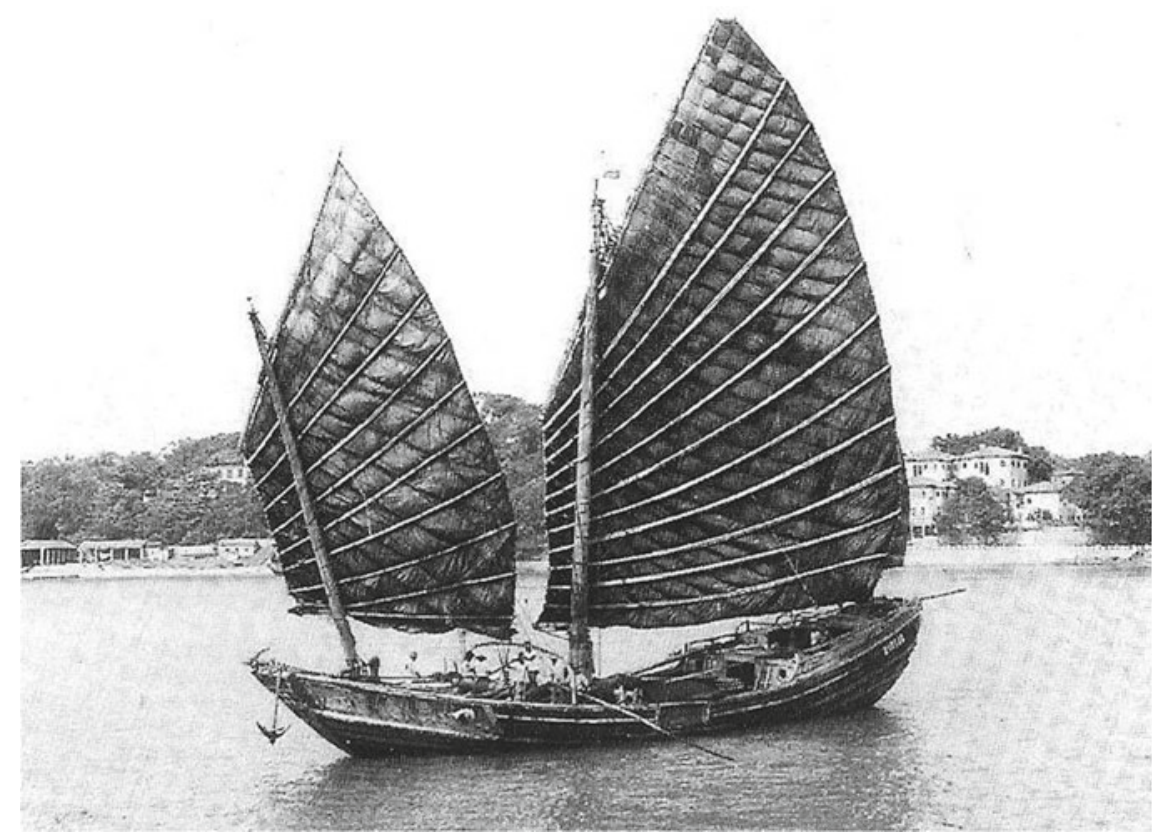

Fig. 5.2 A traditional junk of Fujian (Min) maritime merchant

the Han Dynasty record: "Yue people generally believed in ghosts and their temples were full of various ghosts" (Sima, Q. 1959: 1680; Ban, G. 1962: 1241). The Vol. Fifty-eight of "Temples (祠庙)" of the General Chronicle of Eight Prefectures of Fujian (Bamin Tongzhi 八闽通志) of the Ming Dynasty says: “The customs in Min people fashioned witching and trusted ghosts, and everywhere even the remote mountains were full of various temples and ghosts sacrificing" (Huang, Z.Z. 1991: 365). The section "Peoples (人部)" of the Works Collection of Five Subjects (Wu Zha Zhu 五杂珇) of Ming Dynasty records: “The worship of witches and ghosts were prevalent in the regions to the south of the Yangtze River, and were the most in Guangdong and Fujian" (Xie, Z.Z. 2019: 512). For the reason of acculturation of the indigenous Island $Y i$ and Bai Yue and the cross-cultural acceptance and inheritance by the indigenization of immigrated Han nationality, people living along the coast of south China developed to be an animistic society with multi-ghosts sacrificing and remained to modern society. They commonly worship various kinds of witches and wizards for "life protection and disaster relief", of which the Mother Ancestor (Matsu 妈祖), Dragon Mother (Longmu 龙母), Waterfront Lady (Lingshui Furen 临水夫人) and so on are a few of the typical maritime focused goddesses.

The Matsu, the Mother Ancestor, which originated from Meizhou (湄洲) island in Putian (莆田) in the central coast of Fujian, was the most widely distributed sea goddesses of ancient China, and well known as oriental sea goddess all over the 
world, spreading along the maritime silk road in last hundreds of years. Matsu's original name was Moniang Lin (林默娘), her life story was praised and commented in detail in historical documents. The memorial tablet of the Record of Success God Holy Matsu Temple (Shunji Shengfeimiao Ji 顺济圣妃庙记) of Song Dynasty records: “This daughter of Lin's family in Meizhou of Putian Prefecture could foresee the fortune or misfortune of people when she was a little girl. After she died people built a temple to memorize and sacrifice her. She was recognized as the super witch and dragon's daughter communicating the ghost (Qian-Shuo-You, 1970: 704)." Another tablet of the Record of Bestowing God Holy Matsu Temple (Linhui Feimiao Ji 灵惠妃庙记) in the Song Dynasty tells a similar story: "Miss Lin was born in Meizhou of Putian, where the earth was specially in purple color signifying that the super man will be born... She was recognized as the descendant of dragon and her spirit would cruise wherever like the dragon to protect people." Scholars researched that the "Dragon's Daughter" and "Dragon's Descendant" were in fact the snake totem people of the indigenous system of Southern Man (南蛮) and Bai Yue. According to the tablet of "Record of Rebuilding the Success God Shengdun Ancestor Temple" (Shengdun Zhumiao Chongjian Shunjimiao Ji 圣墩祖 庙重建顺济庙记) and similar records in the previous two tablets, Moniang Lin "was said to be the super female witch capable of communicating with the heaven goddess", the family of Moniang Lin could be originally the hereditary wizard and the cultural heritage of indigenous Bai Yue where "the worship of witches and ghosts were prevalent in the regions to the south of the Yangtze River, and were the most in Guangdong and Fujian" (Wang, R.G.2003: 62-83,244-259)

Dragon Mother (Longmu) is another important water goddess in south of China and mainly worshipped by boat people of both the Han and Zhuang (壮) ethnicities along the Xijiang River Valley and the Pearl River Delta. In the Qing Dynasty, there were 352 Longmu temples and much more Longmu temporary palaces in the Xijiang River Basin, which were generally built in knot points and estuaries of rivers and streams (Huang, G.Q. 2006). Both Han people along the Xijiang and Pearl rivers in the territory of Guangdong and minority Zhuang ethnicity around Damingshan (大明山) mountain in Guangxi worshipped Longmu "Dragon Mother", who was recognized as the "snake mother" and a kind of snake totem worship, indicating their common source of indigenous Bai Yue culture (Fig. 5.3).

In addition, there are a number of other sea gods along the south coast of China originated from the ancient indigenous Bai Yue culture, such as "Water Front Lady" or "Lingshui Furen", "Yangyu God" (演屿神) and “Nagong God" (拿公神) in the estuary of the Minjiang River, Zhaoling Temple (昭灵庙) in Fuqing (福清) (Xie, C. G. 2002; Wang, R.G. 2012). The indigenous origin of these sea gods worships in the south coast of China indicates that the mainstream of the maritime culture of the Han nationality in south China have accepted and inherited the indigenous Bai Yue cultural tradition of prehistory and early history.

Thirdly, the nautical technology of the Han people in coast of southern China also originated from indigenous Bai Yue seafaring activities. Especially, a number of the most important medieval seaport metropolis have directly continued the oceanic capitals of Bai Yue states along the coast, showing the inheritance of regional 
Fig. 5.3 Snake-shaped stone carving in the Dragon Mother temple at Liangjiang (两江) village of Wuming (武鸣)

County, Guangxi (Photographed by Qin Fang覃 芳 of GXICRCA)

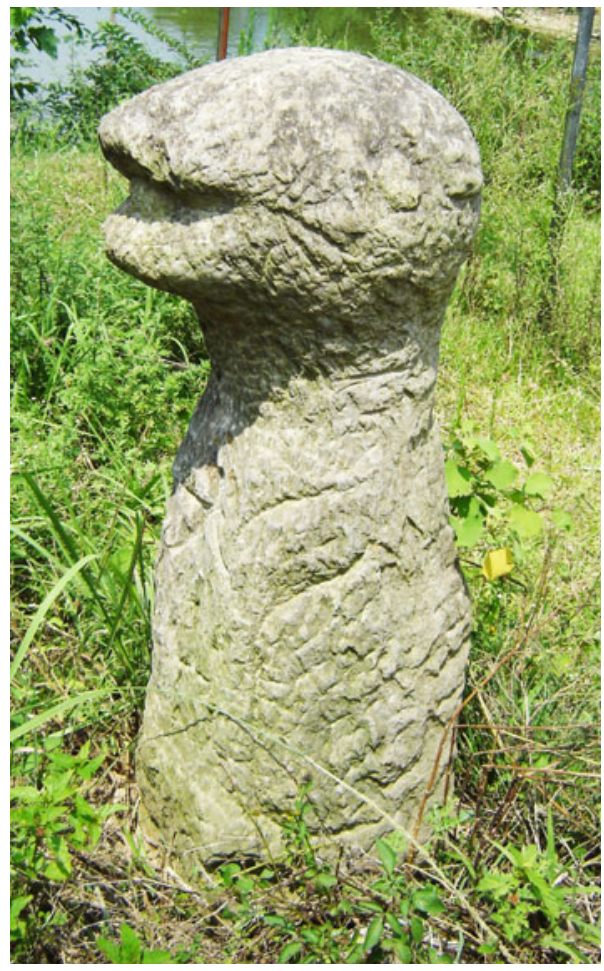

navigation system. Furthermore, the traditional sea routes of the East Ocean and South Ocean of the middle ancient ages have also developed on the base of the indigenous seafaring of prehistoric and early historic ages (Wu, C.M. 2019).

Most of the capital cities of indigenous states of Bai Yue ethnicities in southeast coast of China during Pre-Qin and early Han dynasties were located in the largest river estuary with each state or the ethnic territory, which were the most convenient for seafaring exits. These coastal capital cities are not only linked to the vast hinterland of economy and resource in each state, but also the most convenient seaports for navigation trade of each indigenous society, highlighting the maritime nature of Bai Yue capital cities. They were absolutely different from those of the farming cultural states or kingdoms in the "Center of the World" (天下之中) or “ Big Riverside" (大河之上) of the Central Plain (中原) and the North in pre-Qin to early Han dynasties (Wu, C.M. et al. 1998; Cao, J.2003). After the Han and Jin dynasties, all of these coastal capitals of the Bai Yue states continued and turned to be the main seaports cities and maritime metropolis. For example, Panyu (番禺), the capital of Southern Yue state in the Pearl River Delta developed to be the administrative center of Nanhai Prefecture of the Qin and Han dynasties after indigenous state was repealed, and the largest metropolis in the South China Sea from the Han and Tang to the Ming and Qing dynasties. The seaport capital Eastern Ye (东冶) of Min Yue state rising and developing in the estuary of Minjiang River, 
developed to be the county town of the only one administration division Yexian (冶 县) County under the Kuaiji (会稽) Prefecture since late of Han Dynasty, and one of the most important shipping centers along the southeast coast after the demise of Min Yue state. Hanoi as the largest coastal seaport of north of Vietnam, being situated at estuary of Red River, had been the capital city Co Loa (古螺城) of the indigenous of Luo Yue (骆越国) state and developed to be the administrative center of the Jiaozhi (交趾) Prefecture. The capital city Helv (槛闾) of the Wu state situated at the east coast of Taihu lake in the Yangtze River Delta turned to be the early Suzhou (苏州) city as the administrative center of Wu Prefecture since Qin and Han dynasties, while the capital city Shanyin (山阴) of Yu Yue state near the southern coast of lower reach of Qiantangjiang River turned to be the administrative center of the Kuaiji Prefecture after Qin and Han dynasties, both of them continued to be the flourishing seaport cities in early history around East China Sea. In a word, the maritime cultural nature of capital cities of Bai Yue coastal states laid the economic and cultural foundation of the most important seaport metropolises in southeast of China during the Han and Tang dynasties, which is an important illustration of the inheritance of the maritime culture and navigation system between the indigenous Bai Yue and the indigenized Han people.

Since the Han and Tang dynasties, the formation of the traditional sea routes of the East Ocean, the South Ocean, and the West Ocean, also generally inherited the indigenous Bai Yue seafaring practices between the mainland and islands in Seas Surrounding China, except for some restrictions of the geographical conditions, monsoon, ocean currents, and other environmental factors. In the East China Sea, the East Ocean sea routes carried out by boat people of ancient Minzhong (闽中) in central Fujian were recorded in the navigation guide books such as Sea Routes with Successful Sailing (Shunfeng Xiangsong 顺风相送) of late the Ming Dynasty, showing the round-trip navigation between mainland seaports of Meizhou, Quanzhou, Zhangzhou (漳州) and Nanao (南澳) and alike on the coasts of Fujian and Guangdong, and islands seaports of Penghu (澎湖), Luzon (吕宋), Sulu (苏禄), Boni (渤泥). The Guide for Right Sea Routes (Zhinan Zhengfa 指南正法) also depicted the seascape along the route from Zhangzhou via Penghu and Taiwan to Luzon in Philippines, the round-trip nautical routes listed in the book were more than that in the Sea Routes with Successful Sailing, constituting a complicated net of maritime routes of the East Ocean from mainland southeast of China to the Southeast Asian archipelago (Xiang, D. 1961: 87-99, 137-190). Archaeological investigations revealed that these historical sea routes had been started in the Neolithic seafaring of indigenous Bai Yue and proto-Austronesian from mainland southeast of China, across Taiwan Strait and Bashi Channel of Philippines, and into Southeast Asia and Pacific (Bellwood, P. 1979: 201-202; Rolett, B.V. et al. 2002; Rolett, B.V. 2007; Wu, C.M. 2019). In the South China Sea, from the "South China Sea Route via Xuwen and Hepu” (Xuwen Hepu Nanhaidao 徐闻合浦南海道) in the Qin and Han dynasties, to "Guangzhou Sea Route to Foreign States (Guangzhou Tonghai Yidao 广州通海夷道)” in the Tang and Song dynasties, the navigation practices on the West Ocean and South Ocean routes could also be traced back to the maritime cultural dispersal and connection of the Neolithic 
ancestors of indigenous Southern Yue and Luo Yue along the north and west coasts of South China Sea to Indochina Peninsula (Wu, C.M. 2011a, 2019; Higham, C.F.W. 2019).

In short, the maritime cultural feature of the Han people in southeast coast of China, to a large extent, was formed on the foundation of the prehistoric and early historic culture of the indigenous Island Yi of Bai Yue, which had been deeply accumulated in the society of boat people of Han nationality, with the maritime cultural gene and navigation technologies. Therefore, we cannot analyze the origin of maritime culture of south China prejudicially from the viewpoint of Huaxia or Han centrism of the Central Nation and the North, which misunderstanding the maritime culture of the Han people in southeast coast of China since the Han and Tang dynasties as the "reestablishment" after their immigration from north to south, and the spatially shifting of the Chinese economic center from the north to the south. The cross-cultural foundation of the indigenous Island $Y i$ should have been the major origin of the maritime cultures of Chinese Han people in the southeast of China.

\subsection{The Acculturation of Foreign Maritime Fan in Han People Along the Maritime History of Southeast China}

In the history of the past more than 2000 years, the development of Han people in south China also continuously accepted the acculturation of the foreign maritime ethnicities from South China Sea and the Indian Ocean along the Maritime Silk Road. These foreign maritime groups with "hetero-culture" and "totally different from ours" were generally recorded in Chinese history as maritime "barbarians" of $H u$ (胡), Fan (番), Hui Man or Huihui Fan (回蛮, 回回番, both the Muslin), Devil Fan (番鬼) and alike. In fact, most of them were maritime merchants from various foreign countries along the Maritime Silk Road, landing and trading in Guangzhou, Hepu, Quanzhou, Yangzhou, and other ancient seaport metropolises in southeast coast of China. They mixed and acculturated the local society of Han nationality in varying degrees. These maritime "hetero-cultures" enriched and developed the local maritime cultural connotation of the Han people in south of China, leaving us a large number of colorfully cross-cultural historical heritages (Wu, C.M. et al. 2011).

During the Han, Jin dynasties, and South Dynasties, there were various maritime merchants $\mathrm{Hu}$ and Fan from the South China Sea landing on the seaports of southeast coast of China, which were recorded in Chinese historical documents and witnessed by archaeological discoveries. They made a special cross-cultural exchange in the early development of the Han people in south of China. Guangzhou had been the largest seaport metropolis on the northern coast of the South China Sea and gathered many foreign missions and merchants from countries of the South China Sea and the Indian Ocean. According to the "Annals of Geography" of the History of the Han Dynasty, more than ten foreign maritime states in South China 
Sea and Indian Ocean traded through "South China Sea Route via Xuwen and Hepu”, including the Zhangsai (障塞) of Rinan (日南, now Vietnam) Prefecture, Duyuan (都元, now Sumatra), Ruhmi (邑卢没, now Myanmar), Chenli (谌离, now Myanmar), Fugandulu (夫甘都卢, now Myanmar), Huangzhi (黄支, now India), Pizong (皮宗), Yichengbu (已程不, locating to the south of Huangzhi (Ban, G. 1962: 1671). Historians stated that the kingdom of Huangzhi was the present east coast of India and the Yichengbu (已程不国) was Sri Lanka (Han, Z.H. 1958; Wang, Z.J. 1992). There were many maritime missions and merchants arriving to Guangzhou in the Han Dynasty along this sea route. The "Biography of Western Territory (西域传)” of the History of the Later Han Dynasty (Houhan Shu 后汉书) records: “During the time of emperor Huandi (桓帝) in the Han Dynasty, the king Andun (安敦) of Great Qin (大秦, Roman) empire sent a mission to present tributes of ivory, rhinoceros horns, and tortoise shells via Rinan state, and started the trade since then" (Fan, Y. 1965: 2920). The territory of the Roman empire had been extended to the Persian Gulf and the Red Sea during the time of the Han Dynasty, and the Roman merchants along the sea routes most possibly included a variety of ethnic groups from the south and West Asian coasts. The chapter "Biography of Southern Barbarians and Southwestern Yi (南蛮西南夷列传)" of the History of the Later Han Dynasty also records: “In the first year of Yongning (永宁) reign (AD120) of Andi (安帝) emperor in late Han Dynasty, the King Yon Youdiao (雍 由调) of Shan (掸) state sent missions to the palace paying tributes and presenting hundreds of acrobat performers who were good at singing, dancing, spitting fire, self-dissecting, changing horse head with cow head lively, and ball skipping. These acrobats claimed to be from the West Ocean, where was the territory of the Great Qin. During that time, the Shan (掸) state connected and transported its southwest territory with the Great Qin...During the sixth year of Yongjian (永建) reign (AD131) of Sunidi (顺帝) emperor of the late Han dynasty, the King Bian (便) of the Yediao (叶调) state beyond the territory of Rinan state sent mission paying tributes, Shundi emperor granted him gold seal with purple belt" (Fan, Y. 1965: 2837, 2851). The "Biography of Shundi Emperor (顺帝纪)" of the History of the Later Han Dynasty also confirms: "During the time of the sixth year of Yongjian reign of Shundi emperor, the Yediao and Shan states sent missions to pay their tributes" (Fan, Y. 1965: 258). Yediao state was studied and identified as the present Java or Sumatra, the Shan state was present Burma, and the acrobat performers from Shan state claimed themselves the people from Great Qin. Therefore, the maritime communications with the ethnic groups from South and West oceans had been in a wide range and frequent.

Archaeologically, a series of cultural heritages of the immigrated maritime $\mathrm{Hu}$ or Fan people in Qin, Han dynasties, and Six Dynasties were unearthed in large amounts in southern coast of China. The green glazed pots of late eastern Han Dynasty recently unearthed from Liaowei (寮尾) cemetery site in Hepu county of Guangxi were studied and identified as the product in the Parthia empire (247 BC-AD 226), which were different from traditional Chinese pottery artifacts. This pottery pot had been an ordinary household vessel instead of a commodity or an inherited treasure, so it could be inferred that the owner of the tomb might have 
been a maritime $\mathrm{Hu}$ or Fan merchant from Parthia in the Han Dynasty (Huang, S. 2012). In the tombs of the Han Dynasty and Six Dynasties along the southeast coasts of Guangdong, Guangxi, Jiangsu, and Zhejiang, many human figurines of pottery and bronze with short skull, prominent cheekbone, deep eye, high nose, and small stature, were respectively discovered, obviously different from those of local Han people or East Asian ethnicities. In Guangxi, the bronze human figurine excavated in the tombs of West Han Dynasty at Fengliuling (风流岭) site in Guixian (贵县) County was built with high nose, deep eye, full beards, and wearing hats. The human figurine shaped pottery lamp unearthed in the Han Dynasty tomb in Wangbu (旺步) site of Wuzhou (梧州) was built with high nose, deep eye, sticking tongue out of mouth, heavily bearded and dense body hair, naked and barefoot. Another human figurine shaped pottery lamp unearthed at High School campus site of Guixian county was built with prominent eyebrows, triangle eyes, high nose, sticking tongue out of mouth, heavily bearded and dense body hair, naked and barefoot. Similar pottery human figurines with hetero race features were also discovered in many sites along the coast of Guangdong, especially around Guangzhou, the original land of Panyu seaport of Southern Yue metropolis, such as pottery lamp from the tomb of Han Dynasty at No.5 of Xianlie Road (先烈路), with foreign $\mathrm{Hu}$ or Fan figurine shape of high nose, point chin, and full bearded. About ten pieces of this type pottery lamps have been discovered from the tombs of the Han Dynasty in Guangzhou including M3021:87, M3026:6, M4019:39, M5018:1, M5036:22, M5032:12, M5063:1, M5043:21, M5061:2, and M5046:16, with foreign $\mathrm{Hu}$ figurine shape of sticking tongue out of the mouth, heavily bearded, naked, and barefoot (Fig. 5.4a, b). Around Guangzhou, the human figurine shaped pottery lamps of the early Eastern Han Dynasty unearthed in Chencun (陈村) of Shunde (顺德) were usually built with square faced, high nose, thick eyebrow and the triangular eyes, two sideburns, naked and barefoot, dense body hair and exposing penis. At Wentougang (文头岗) site of Panyu, high-nosed and heavily bearded pottery figurines of foreign $\mathrm{Hu}$ or Fan people wore dresses in Chinese Han style (GXZMCRAT 1984; Deng, L. 2006; GZMICRA 2005a, b; Xiong, Z.M. 2000; GZMCRAC et al. 1981; GDPM et al. 1991). In coastal regions of Jiangsu and Zhejiang, similar burial figurines with foreign $H u$ ethnic features were also discovered in the tomb of Three Kingdoms period in Jiangning (江宁) and tombs of East Jin Dynasty at Fuguishan (富贵山) of Nanjing in Jiangsu (Fig. 5.4c). On the celadon burial jars unearthed from the tombs of the Six Dynasty in Jiangsu and Zhejiang were usual the sculptures of human figurines of $\mathrm{Hu}$ and Fan people. For example, in the tomb of the western Jin Dynasty in Pingyang (平阳) county of Zhejiang, there were a group of sculptures of music band including the figurine of the players of $\mathrm{Hu}$ ethnic with deep eyes, high noses wearing pointed hats (Xu, D.S. et al. 1988; Li, G. 1991).

Researchers presented opinions on the origin and identification of these foreign human figurines "totally different from ours". Some of them augured that these obviously hetero races were the foreign $H u$ who had been sold to Lingnan (岭南) coast to be the slaves of local family of Han nationality, they also considered that these foreign $\mathrm{Hu}$ "might be the native Indonesians, or primitive Malays in the South 
a

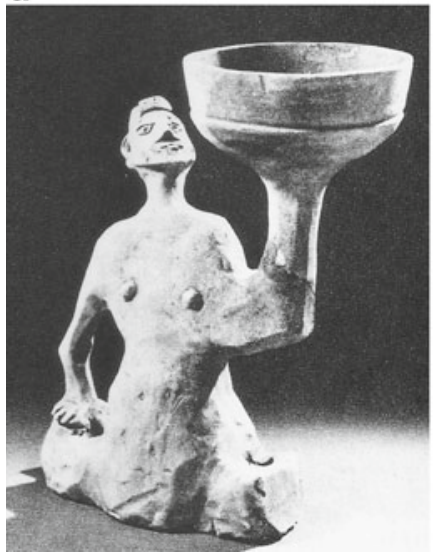

b

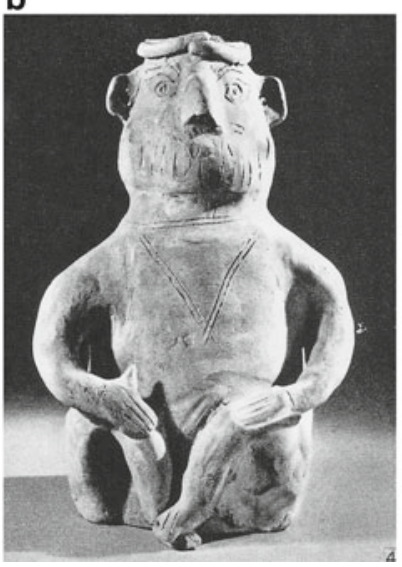

c

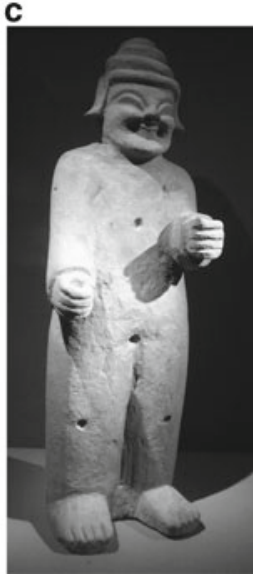

Fig. 5.4 Burial pottery figurines of Maritime Fan discovered in southeast coast of China (a. M3026:6, Western Han Dynasty in Guangzhou; b. M5046:16, Eastern Han Dynasty in Guangzhou; c. Tomb of East Jin Dynasty at Fuguishan 富贵山 of Nanjing in Jiangsu)

China Sea," or "probably from India", or "more likely from the east coast of the West Asia or Africa" (Hu, Z.C. et al. 1961; Huang, Z.Y. 1984; GZMCRAC et al. 1981: 478). Other scholars argued that "those pottery human figurines of $H u$ with naked and barefoot features unearthed from the tombs of the Han Dynasty in Guangzhou were clearly the images of Jain of southern Indian for their distinctive nudity worship" (Li, G. 1991). In any case, these pottery figurines of the hetero human races discovered in southeast coast of China during Qin, Han dynasties, and Six Dynasties vividly revealed the mixture and acculturation of the immigrated foreign $\mathrm{Hu}$ and local Han people during the early development of Maritime Silk Road around South China Sea.

During the Tang and Song dynasties, the coastal seaport cities in south of China continued to be the converging lands for foreign maritime merchants as Various Fan (诸番), Huihui Fan, among them, many were Muslim merchants. They landed and settled for bushiness in Guangzhou, Quanzhou and Yangzhou, and other seaport metropolis, mixed with the local people and were assimilated into Chinese societies, promoting the development of maritime culture of the Han nationality of south of China. The "Annals of Geography" of the New History of the Tang Dynasty (Xingtang Shu 新唐书) records, there were dozens of countries and seaport cities along the "Guangzhou Sea Route to Foreign States" in the South China Sea and Indian Ocean, where were supposed to be major sources of these foreign Fan merchants in the Tang and Song dynasties (Ouyang, X. et al. 1982: 1153). The chapter of the "Geography of Wang E (王鍔传)" of the same book records: "The great profits of foreign maritime merchants in Guangzhou were mostly deprived by Wang E family. His family sent more than ten commercial boats with rhinoceros, ivory and pearl shell exiting to trade overseas and became much more wealthy than other officials in 
capital" (Ouyang, X. et al. 1982: 5169). The chapter of the "Geography of Wang Fangqing (王方庆传)” of the Old History of the Tang Dynasty (Jiutang Shu 旧唐书) records that "Guangzhou situated on the coast of the South Sea, merchants of Kunlun (昆仑) state come from West Sea by ships with treasure to trade each year" (Liu, Xu 1975: 2897). According to the records in Old History of the Tang Dynasty and New History of the Tang Dynasty, the foreign commercial boats converging to Guangzhou in the Tang Dynasty included the South Sea Boat (南海舶), Western Barbarian $Y i$ Boat (西方夷舶), Persian Boat (波斯舶), Western Regions Boat (西域舶), Barbarian Fan Boat (番舶), Southern Barbarian Fan Boat (南蕃海舶), Barbarian Man Boat (蛮舶), Kunlun Boat (昆仑舶), Boromen Boat (波罗门舶), Lion State Boat (狮子国舶) and so on, showing the diverse origins of the foreign maritime merchants. The Biographical Record of the Great Monk of Tang Dynasty (Tang Daheshang Dongzheng Zhuan 唐大和上东征传) records what monk Jianzhen (鉴 真) saw in Guangzhou, “There were countless boats from Boromen (波罗门), Persia, Kunlun (昆仑) and alike, with heavy loads of spice, medicine, and treasure. The boat was six to seven zhang (丈) deep. People from various foreign states of Lion (Shizi Guo 狮子国), Dashi (大石), Gutang (骨唐), ‘white barbarian’ Bai Man (白蛮) and 'red barbarian' Chi Man (赤蛮) lived there” (Oumino, M. 2000: 74). At the time, the Arabian businessman Sulayman (苏莱曼) wrote in his book Voyage Du Marchand Asabe Sulayman Par Sutayman that "The Kaufu (Canton, now Guangzhou) is the Chinese seaport where the Arabian merchants lived in China. There is a Muslim imam and a mosque. It is also the main entrepot for Chinese and Arabian merchants as well as their cargoes" (Sulayman 1937). In the "Chronicles of Locality (方域志)" of the History of Min Kingdom (Min Shu 闽书) written in the Ming Dynasty records that "two Arabian merchants were buried in Lingshan (灵山) mount of Quanzhou, who were the earliest Muslin merchants living there. The Muslim say that four Muslim missionaries preached in China during the time of Wude (武德) reign in the Tang Dynasty, one was in Guangzhou, one in Yangzhou, and two in Quanzhou" (He, Q.Y. 1994: 165-166) In addition to foreign merchants and envoys for tributes, a considerable number of foreigners at the time were sold there as slaves. After monk Jianzhen failed in sailing to Japan for the wrong current and drifted to Hainan island in the seventh year of Tianbao (天宝) reign (AD 748) in the Tang Dynasty, he stayed at the home of a chief Feng Ruofang (冯若芳) in Wangan (万安) Prefecture in Hainan. He knew that the chief Feng robbed two or three Persian merchant ships every year, took the cargoes and sold the people of the ships as slaves. These slaves sold by the chief distributed in many local villages around the prefecture (Oumino, M. 2000: 74).

Since Song and Yuan dynasties there were more and more foreign merchants living in China. According to the "Record of Food and Commodity (食货志)" of the History of Song Dynasty (Song Shi 宋史), “The governments established Shibosi (Foreign Commercial Boat Administration 市舶司) custom office in Guangzhou in the fourth year of Kaibao (开宝) reign (AD 971) and then again in Hangzhou and Mingzhou (now Ningbo) to superintend the foreign trade. During the time, these coast seaports opened trade for the diverse merchants from foreign states such as Dashi (Arab Empire 大食), Kalah (古逻, now south of Malay peninsula), Dupo (阇婆, Yavadvipa, now Java), Champa (占城, southeast 
Vietnam), Burni (渤泥, now Borneo), Mait (麻逸, now Mindoro of Philippines) and Samboja (or Srivijaya, 三佛齐, now Sumatra)" (Tuotuo 1977: 4558-4559). According to laws of Song Dynasty in Collected Important Administrative Statutes of the Song Dynasty, "There were many foreign and Chinese merchants living together in Guangzhou where had no city walls. Despite the coastal guard patrolling in the sea, the pirates were active and the merchants were usually robbed" (Xu, S. 1957: 7472). Hong Kuo (洪适) also wrote in his Panzhou Collected Works (Panzhou Wenji 盘洲文集), “Guangzhou was a large seaport metropolis where the rich merchants from Dupo, Champa, Burni, and Samboja sailed to and settled down. Dozens of cargo ships reached very year loading with treasures of rhinoceros horns, ivory, pearls, incense and countless types of indescribable goods from the barbarian states in the southwest ocean" (Hong, K. 2004).

The landing and residing of a large number of foreign maritime barbarians Fan and Huihui Fan changed the demographic composition of coastal seaport cities such as Guangzhou, therefore a series of settlement communities Fan Fang (蕃坊) and cemeteries Fan Ren Zhon (蕃人冢) special for these foreigners was set up in these cities. Zhu Yu (朱或) says in his Record of Pingzhou Table Talk (Pingzhou Ketang 萍洲可谈), “The foreign settlement communities Fan Fang in Guangzhou was exclusive for foreigners, being administrated by an official specially in duty to manage the foreigner affairs in the community" (Zhu, Y. 1985: 19). A lot of the local citizens in Guangzhou also used foreign Fan as slaves. Zhu Yu revealed more information in last book: "The rich families in Guangzhou usually hired foreign barbarian slaves who were strong and could carry heavy load. These slaves could not speak the local dialect and would not escape from their masters. They were from oversea mountainous regions, in black skin and with yellow curls hair, being regarded as wild men...It was said that there were wild men in the oversea coastal areas who could dive into water with open eyes and were called Kunlun slaves" (Zhu, Y. 1985: 20) Archaeologically, the foreigner's cemetery Fan Ren Zhon and Muslim cemetery Huihui Fen (回回坟) in Guangzhou were investigated in northeast of Liuhuaqiao (流花桥) Park in north of the city and the northwest foothill of Yuexiu (越秀) Mountain where Muslim sages, imam, Chinese and foreign Muslims had been buried since the Tang Dynasty (Zhong, Y.X. et al. 1989: 71, 13-117; Pan, G.P. 2015). The chapter “Other Record (杂录)” in the Vol. One Hundred and Sixty in the Chronicle of Guangzhou Prefecture (Guangzhou Fuzhi 广州府志) of Guangxu (光绪) reign records: "During the Tang Dynasty, the king of Muslim Modena (默德那) state in the western regions dispatched his mother's brother Suha Pesai (苏哈白塞) as the imam to trade in China, who built a Huaisheng (怀圣寺) minaret and mosque in Guangzhou and was buried in Huihui Fen cemetery after he died" (Shi, C. 1966: 783). But the earliest grave monument investigated here was "Hamad Tombstone" which was built up in the year 712 of Muslim calendar (AD 1312) with Arabian epitaph for the deceased of the Arabian Abdallah Hamad (Chen, H.J. 2005; Fig. 5.5). Another later one was set up in the year 727 of Muslim calendar (AD 1327) with an Arabian epitaph for the deceased Arabian soldier Aladdin Bi Kasimle (Yang, T. 2008). 
Fig. 5.5 Grave monument of Arabian Abdallah Hamad dating to 712 of Muslim calendar (AD 1312) in Guangzhou

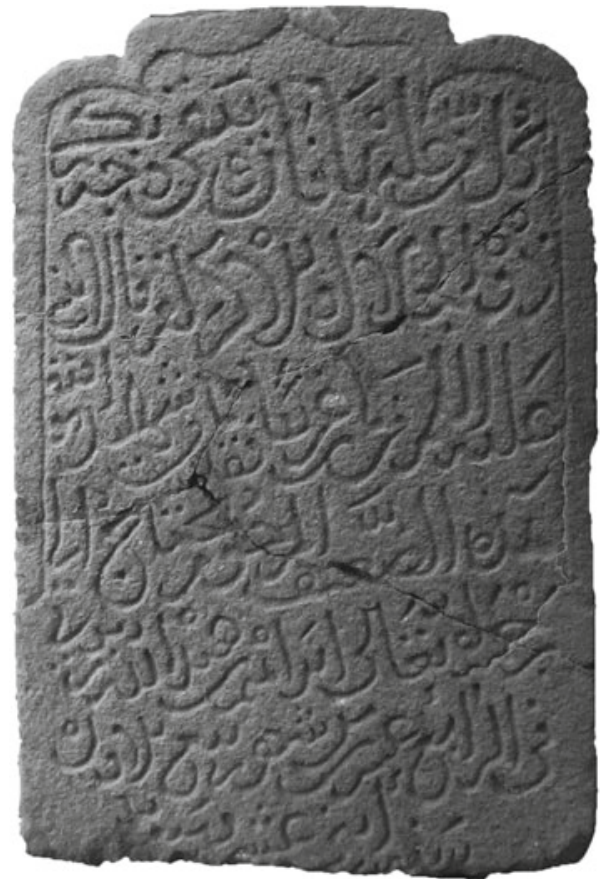

During Tang and Song dynasties, Quanzhou was another big seaport matching Guangzhou. According to the History of Min Kingdom cited in previous chapter, two of the four Muslim missionaries preaching China during the time of Wude reign in the Tang Dynasty arrived in Quanzhou, showing the importance of it in the oversea trade and international relationships. In the Tang Dynasty Quanzhou was an international metropolis with large number of foreign residents from Arab, Morocco, India, Sri Lanka, Persia and Syria, most of which were Arabian. With the arrival of many Arabian merchants Quanzhou developed into one of the world's largest harbors in the Song and Yuan dynasties, resulting the setting up of Shibosi custom office in the second year of Yuanyou (元佑) reign (AD 1087) in Yuan Dynasty. The Biography of the Foreign Nations (Zhufan Zhi 诸蕃志) states in the section of "Dashi State (Arab, 大食国)", “There was an Arabian merchant Shinawei (施那帏) who lived in the south of Quanzhou and built a cemetery to bury the dead foreign merchants in Quanzhou" (Zhao, R.S. et al. 2000: 91). In the Yuan Dynasty, Wu Cheng (吴澄) recorded in his Works Collections of Authority $W u$ Wengzheng that Quanzhou had been the metropolis city in Seven Min region of ancient Fujian, where the exotic treasures and rare curios from far foreign states had been imported and stored, with many residences of business tycoons and wealth merchants (Wu, C. 1985: 300-301). The great traveler Marco Polo also claimed that "Quanzhou was one of the largest seaports in the world, a large number of merchants came there to trade, and various kinds of cargoes piled up like mountains" (Komroff, M. et al. 1981: 192). The Vol. seventy-five of the Chronicle of 
Quanzhou Prefecture (Quanzhou Fuzhi 泉州府志) published in Qianlong (乾隆) reign of Qing Dynasty recorded that "some foreign merchants coming by boats were very rich with millions of wealth and lived in the south of the city" (Huang, R. 2000: III 658). The south region of Quanzhou city had been the main settlement community of Muslim next to the Quanzhou Bay, where the dock region of Houzhu seaport, and the Shibosi custom office were located. Now there still preserves a Muslim mosque of Yuan Dynasty on Tumen (涂门) street (Fig. 5.6), Muslim missionaries cemetery of Yuan Dynasty at Lingshan (灵山) (Fig. 5.7). A large number of architectural connotations of Brahmanism culture in Kaiyuan (开元) Temple, and various stone tablet inscriptions or tombstones of Islamism, ancient Christianity (including Nestorianism or Manichaeism) and Hinduism, were discovered in the urban and suburbs of the city so far (Figs. 5.8 and 5.9). In Cao'an (草庵) Temple of Jinjiang a Manichaeist heritage of the Yuan Dynasty has also been identified (Zhuang, W.J. 1989: 170-303; Salam, A.S. 2012).

A lot of scholars believed that in the Tang, Song, and Yuan dynasties there were tens of thousands of foreign merchants reached to southeast coast of China who played a key role in managing the maritime trade between China and foreign countries. "The role of foreign merchants in the history of China's long distant maritime trade before sixteenth century was more important than that of Han nationality in the south of China, only was replaced afterward by Han merchants, especially by the merchants from south of Fujian" (Zheng, Y.C. 2008). A significant proportion of these hetero-cultural maritime merchants resided in China, and in some densely populated areas even assimilated into new maritime ethnic cultures varying in two types. One was the assimilated Muslim immigrant

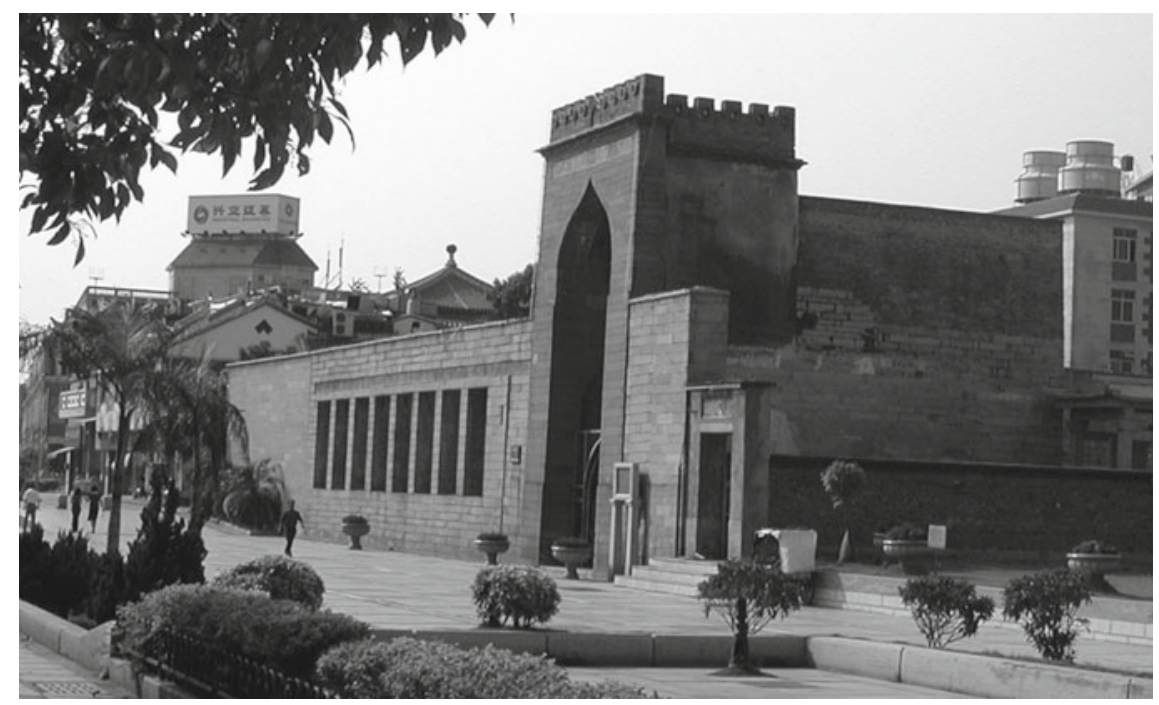

Fig. 5.6 Muslim mosque "Qingjing Temple” (清净寺) of Yuan Dynasty on the Tumen (涂门) street of Quanzhou 


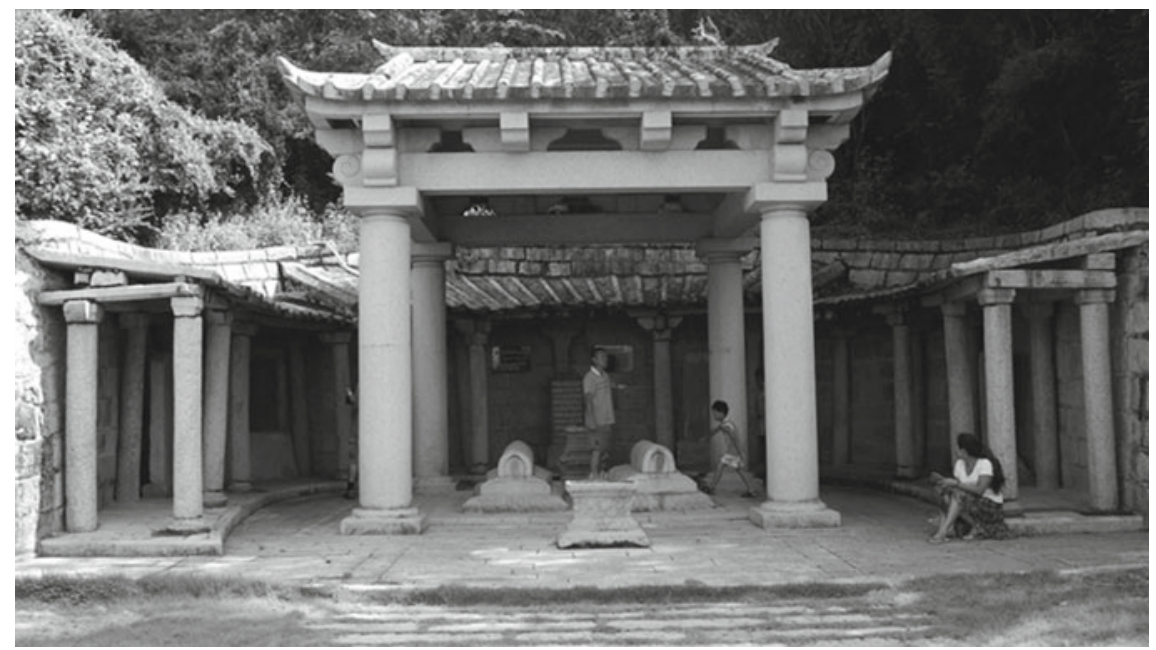

Fig. 5.7 The cemetery of Muslim missionaries of Yuan Dynasty at Lingshan (灵山) of Quanzhou

Fig. 5.8 A Nestorianism tombstone of Yuan Dynasty unearthed in Quanzhou

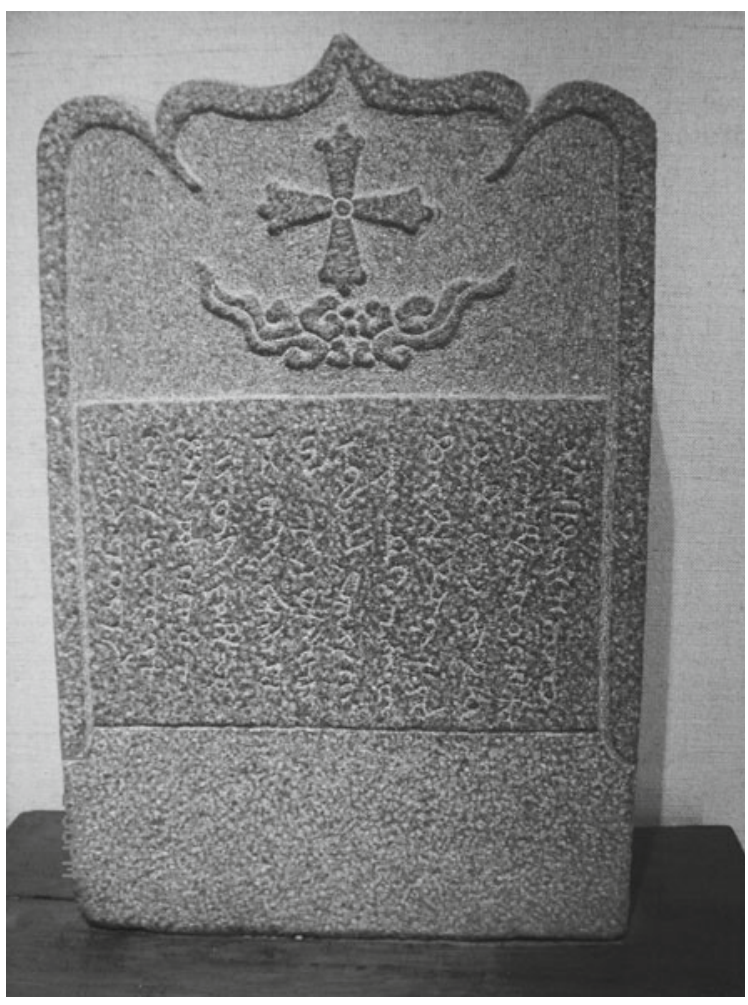




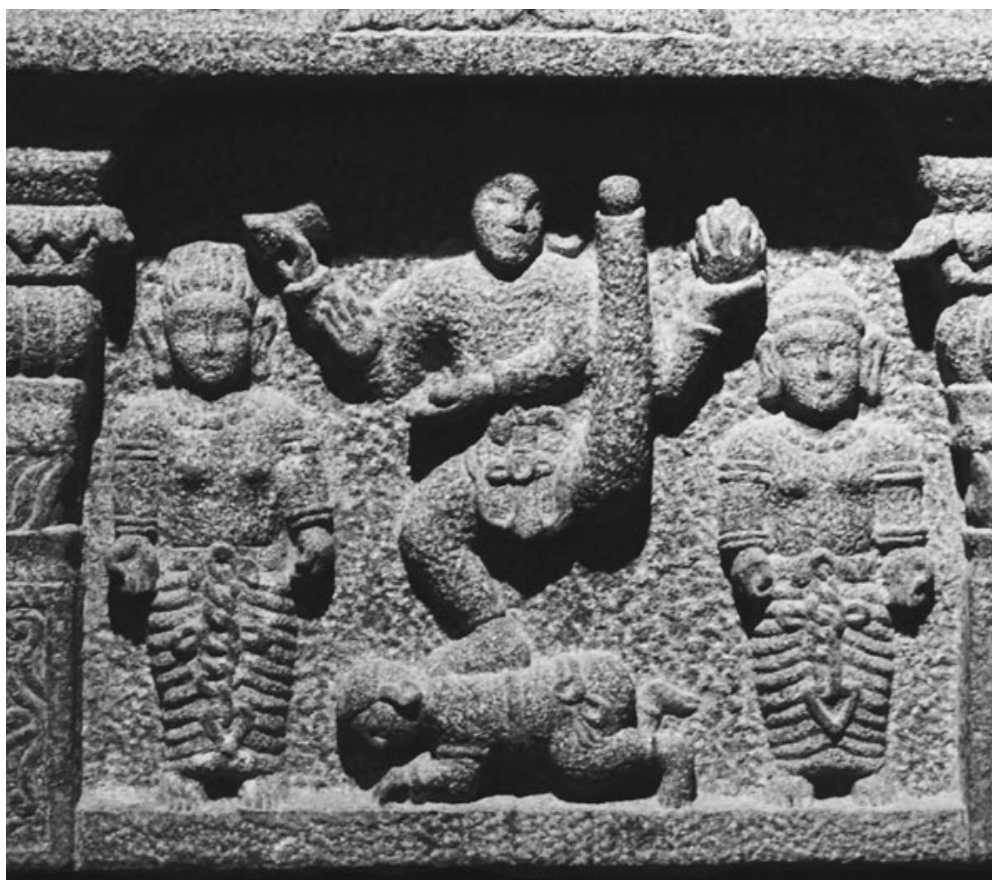

Fig. 5.9 A stone sculpture of dancing Shiva of Hinduism of Yuan Dynasty unearthed in Quanzhou

groups who sailed to the coast of China via South China Sea and Indian Ocean, and still relatively preserved a lot of their own original cultural features. A number of small groups of Muslim Huihui Fan scattering on the coastal areas in Fujian and Guangdong gradually formed new maritime ethnicities after thousands of years of cultural assimilation, such as the Muslims population of Chen Dai (陈埭) village in Jinjiang (晋江) and Baiqi (白奇) village in Hui'an (惠安), Fujian. Their predecessors sailed eastward along the Maritime Silk Road and landed on the southeast coast of China, preserving a distinct maritime cultural tendency, and living on the maritime collection and oversea trade. They were famous navigators and maritime merchants for generations, actively engaged in the maritime trading sailing along the upper-northward (上北) sea routes to reach as far as Tianjin and Tanggu (塘沽), down-southward (下南) sea route to mainland coast of Southeast Asia, and eastward to Taiwan and Philippines since Ming and Qing dynasties, enriching the maritime cultural connotation of the unity with Assimilation and Integration of Pluralistic Cultures of China (Huang, T.Z. 1990; Shiming 1993). Another type of cultural change has been the assimilation of those foreign Maritime Fan into the local Han nationality in south of China. A large number of ethnic groups of $H u$ and Fan with diversely cultural origins along the Maritime Silk Road, being continuously mixed and assimilated into the local Han nationality during last more than 
two thousand years. This mixture and assimilation enriched the connotations of the Han nationality in south China. They did not preserve their original cultural memories and independent ethnic identification. The Collected Important Administrative Statutes of the Song Dynasty records that "in the fourth year of Zhenghe (政和) reign (AD 1111), the emperor decreed that those merchants of foreign Maritime Fan who had lived in China for five generations and their properties had no legal inheritors, or without legal wills and offspring, their properties should be detained by Shibosi custom office" (Xu, S. 1957). The Tablet Inscription of "Introduction of the Rebuilding the Seagod Temple of South China Sea" (Chongxiu Nanhai Shenmiao Bei 重修南海神庙碑) in the Song Dynasty records, "At that time people lived mixing together with foreign barbarians Fan and Islands Yi and maritime merchants from all over the world" (Zhang, W.Z. 2008). The main body of the ethnic groups of $\mathrm{Hu}$ and Fan, whose historical cultural heritages of the Han, Tang, and Song dynasties were investigated in Hepu, Guangzhou, Quanzhou, and Nanjing and discussed in previous paragraphs, have been most possibly assimilated into Han and other local nationalities in south of China. In last 30 years, more than 20 pieces of tombstone inscription of immigrated Shi (世) family cemetery were collected in the Dongyue (东岳) mountain in northern suburb of Quanzhou and other places, presenting a vivid example of cultural assimilation of foreign Maritime Fan with Han nationality. Referring to the genealogy Shi and Xu Shi (许世) families in Quanzhou and those emigrating to Changhua (彰化) of Taiwan, and the related local chronicles, it can be concluded that both groups of Shi and Xu Shi families were the descendants of ancient Sri Lankan envoys and merchants who immigrated to central Fujian and were Sinicized as a part of Han nationality (Wang, S.D. 1999; Wu, Y.X. 2005). Therefore, the foreign maritime $\mathrm{Hu}$ and Fan people coming from the South China Sea and Indian Ocean since Han, Tang, Song, and Yuan dynasties have been significant and constructive sources for the maritime essence of the Han culture in south China.

Furthermore, since the late Ming Dynasty, the geographical discoveries by Europeans, the opening of the global sea routes, the arrival of Portuguese, Spanish, Dutch, British, French, Swiss, Danish, German, American, and other Western merchants to East and Southeast Asia, not only brought profound cultural communications and changed the inherent composition of the coastal societies, but also brought the latest waves of foreign migration and ethnic assimilation in the southeast coast of China. Taking the example of Macau, after originally being settled by Portuguese, many colored people from Africa, Iran, Indian, Bengal, Malacca, and Timor were biasedly regarded as "Black Slaves Heinu" (黑奴), “Ghost Slaves Guinu” (鬼奴), "Black Ghosts Heigui” (黑鬼), “Dark Ghost Wugui” (乌鬼), “Black Barbarian Fan” (黑番) and “Barbarian Ghost Fangui” (番鬼), landed and lived in the city (Tang, K.J. et al. 2005). Then the ethnic miscegenation and cultural assimilation were a common phenomenon in Macau. Almost all Portuguese in Macao married Chinese women, not only the daughters of wealthy families but also the female slaves or common civilians. The Chinese-Portuguese half-blooded and Eurasian hybridized have been the main part of the native-born Portuguese population in Macau. Guangzhou was another bridgehead for the 
importation of western cultures to China, leaving a great amount of historical relics of Euro-American migration. In the foreigners' cemetery Fan Gui Hill (番鬼山) at Shenjing (深井) mountain in Changzhou (长洲) street, Huangpu (黄埔) district of Guangzhou, there are still more than 200 foreigners tomb remains of dead British, Danish, Dutch, Spanish, Swedish and American of eighteenth century (Pan, G. P. 2015). These coming Euro-American influenced the Han people in southern coast of China, and further strengthened their maritime cultural essence.

\subsection{Conclusion}

As an instinctively regional ethnic community prominent with the maritime character in the unity of the "Assimilation and integration of Pluralistic Cultures" of Chinese nation, in the process of its formation and development, the Han ethnic population in coastal regions of southeast China grew up both on the inheritance and assimilation of the indigenous "barbarian" Island Yi of Bai Yue culture in prehistory, and respectively acculturation of the series immigrated ethnicities of foreign Maritime Fan since medieval age of ancient China. The Han nationality of southern or southeastern coast of China developed the unique sailing technology of Chinese Junk, promoted the formation and transition of the navigation sea routes in “Four Oceans" (四洋) and the traditional Maritime Silk Road, which have greatly and indispensably enhanced the excellent prominences of Chinese maritime culture and the integrated Chinese civilization.

\footnotetext{
Open Access This chapter is licensed under the terms of the Creative Commons Attribution 4.0 International License (http://creativecommons.org/licenses/by/4.0/), which permits use, sharing, adaptation, distribution, and reproduction in any medium or format, as long as you give appropriate credit to the original author(s) and the source, provide a link to the Creative Commons license, and indicate if changes were made.

The images or other third party material in this chapter are included in the chapter's Creative Commons license unless indicated otherwise in a credit line to the material. If material is not included in the chapter's Creative Commons license and your intended use is not permitted by statutory regulation or exceeds the permitted use, you will need to obtain permission directly from the copyright holder.
} 